\title{
AN ANALYSIS OF TRENDS IN MOBILE COMMUNICATION SERVICES IN INDIA
}

\author{
by
}

${ }^{1}$ Mrs.Reena Shyam

\begin{abstract}
The world is an ever growing one and would not be possible without telecommunications. The communication industry is one which connects all individuals and even machines through data to truly make the world a global village.

The Indian mobile market has undergone a revolutionary change over the past few years to become one of the leading mobile markets on the global map. The telecom industry has enjoyed a significant upswing and is presently on a high-speed growth path, enjoying a growth rate of approximately $45 \% \mathrm{pa}$, among the highest in the world. This growth in the telecom sector has been facilitated by liberal policies of the Government has played a crucial role in attracting FDI in India.

The paper aims to analyze the changing features of mobile communication services in India. The current technological advancements have caused a paradigm shift. The advent of $3 \mathrm{G}$ in India has brought with it a host of expectations not only by consumers but also service providers alike. As if this wasn't enough, Mobile Number Portability (MNP), which has been launched nationally, will further fuel the already strong wars between operators. This in turn will further consumer churn rate and enhance quality of service provided by operators. The paper provides an insight on the implication of these changes on service delivery of mobile communications and its influence on the continuously expanding subscriber base.
\end{abstract}

Key Words: Mobile communication, FDI, 3G, MNP, Churn rate, MVAS

The telecom industry today is globally viewed as one of the prime movers of the modern economy. Recent changes in telecommunication have transformed the lives of thousands of people. This transformation has been brought about by the aggressive and sustained growth of the mobile Industry, which has progressed over the recent years. The provision of a world-class telecommunications infrastructure has become the key to rapid economic and social development of a country. Despite the challenges of the current industry environment; mobile subscriber growth continues with the emerging markets leading the way.

The Indian mobile market has undergone a revolutionary change over the past few years to become one of the leading mobile markets on the global map. Easy availability of low-priced devices, better network coverage and affordable services are some of the major factors that have boosted its growth and will continue to do the same in future.

\section{THE INDIAN SUBSCRIBER BASE - THE GROWTH CONTINUES}

It has been a momentous year for the telecom sector, with mobile subscribers hurtling towards the 800 million mark and gross revenues crossing $\$ 20$ billion according to the Telecom Regulator TRAI. Projections suggest that India will achieve 893 million wireless subscribers by 2012 \& 1,243 million wireless subscribers by 2015. This growth comes with economies of scale. India boasts of the lowest tariffs

1 Faculty, P.G Department of Management Studies, M.S.Ramaiah College of Arts, Science \& Commerce, M.S.R.I.T Post , Bangalore 560054 reenashyam1 @ gmail.com Mob: 9448201502

No: 38, "Reena Villa" 5th Cross, S.B.M Colony, Brindavanagar, Mathikere, Bangalore -560054 
in the world leading to lowest ARPU's of \$3/ subscriber/month, combined with the highest minutes of usage.

The cell phone segment has been growing at an average rate of 85 per cent in India. And industrialists predict that the growth will continue for a few more years. Four factors will drive growth of the mobile subscriber base: footprint expansion by existing operators especially in rural India, launch of operations by newer operators, issuing of $3 G$ licenses which will open up a new world of data services, and cheaper handsets which will even further lower entry barriers.

\begin{tabular}{|l|r|r|r|r|}
\hline \multicolumn{5}{|c|}{ Indian Wireless Connections - November 2010 C MEDIANAMA } \\
\hline Telcos & \multicolumn{1}{c|}{ Oct - 10} & \multicolumn{1}{c|}{ Nov - 10 } & \multicolumn{1}{c|}{ Additions } & \multicolumn{1}{c|}{ Change } \\
\hline Bharti Airtel & $146,293,078$ & $149,394,064$ & $3,100,986$ & $2.12 \%$ \\
\hline RCOM & $119,351,438$ & $122,362,957$ & $3,011,519$ & $2.52 \%$ \\
\hline Vodafone & $118,038,168$ & $121,163,116$ & $3,124,948$ & $2.65 \%$ \\
\hline BSNL & $80,739,935$ & $83,730,098$ & $2,990,163$ & $3.70 \%$ \\
\hline Tata Teleservices & $80,817,298$ & $82,598,138$ & $1,78,840$ & $2.20 \%$ \\
\hline Idea Cellular & $76,023,551$ & $78,825,800$ & $2,802,249$ & $3.69 \%$ \\
\hline Aircel & $47,519,629$ & $48,738,940$ & $1,219,311$ & $2.57 \%$ \\
\hline MTNL & $5,342,039$ & $5,377,405$ & 35,366 & $0.66 \%$ \\
\hline Loop Telecom & $3,009,445$ & $3,028,695$ & 19,250 & $0.64 \%$ \\
\hline MTS & $7,121,765$ & $7,776,976$ & 655,211 & $9.20 \%$ \\
\hline Uninor & $13,748,300$ & $16,198,124$ & $2,449,824$ & $17.82 \%$ \\
\hline HFCL & $1,132,477$ & $1,432,139$ & 298,662 & $26.37 \%$ \\
\hline S Tel & $1,867,060$ & $2,068,456$ & 201,396 & $10.79 \%$ \\
\hline Videocon & $5,616,152$ & $6,743,803$ & $1,127,651$ & $20.08 \%$ \\
\hline Etisalat + Allianz & 70,829 & 132,052 & 61,223 & $86.44 \%$ \\
\hline All Operators & $\mathbf{7 0 6 , 6 9 1 , 1 6 4}$ & $\mathbf{7 2 9 , 5 6 9 , 7 6 3}$ & $\mathbf{2 2 , 8 7 8 , 5 9 9}$ & $\mathbf{3 . 2 4} \%$ \\
\hline
\end{tabular}

Source: MediaNama

\section{FLOW OF FDI INTELECOMMUNICATION SECTOR IN INDIA}

In the 1990's the telecommunication sector remained a State monopoly. Privatization of this sector remained a dream. And today, a revolution has swept across the country, attracting loads of foreign investment. The cumulative inflow of foreign domestic investment (FDI) into the telecom sector during the last decade was well above Rs. 43,000 million. In fact, the telecom sector attracted the biggest FDI in any sector in India.

The telecom sector requires huge investments for its expansion as it is capital-intensive and FDI plays a vital role in meeting the fund requirements for expansion of the telecom sector. Telecom accounts for almost $10 \%$ of the total FDI inflows in the country and has been the third-largest sector to attract FDI in India in the post-liberalization era. The Indian telecom industry has been an attractive avenue for foreign investors over the years. 
Now that the FDI is being raised from 49 per cent to 74 per cent, India's telecom industry is poised for an unbelievably giant leap. The telecom revolution has placed India's economy on a fast track, heralding prosperity. The last couple of years have witnessed investments of a whooping 8.5 billion dollars in this sector with 550 million dollars being in the form of FDI. The Industry, unlike others was not hit to a great extent by the recent slowdown in the economy.

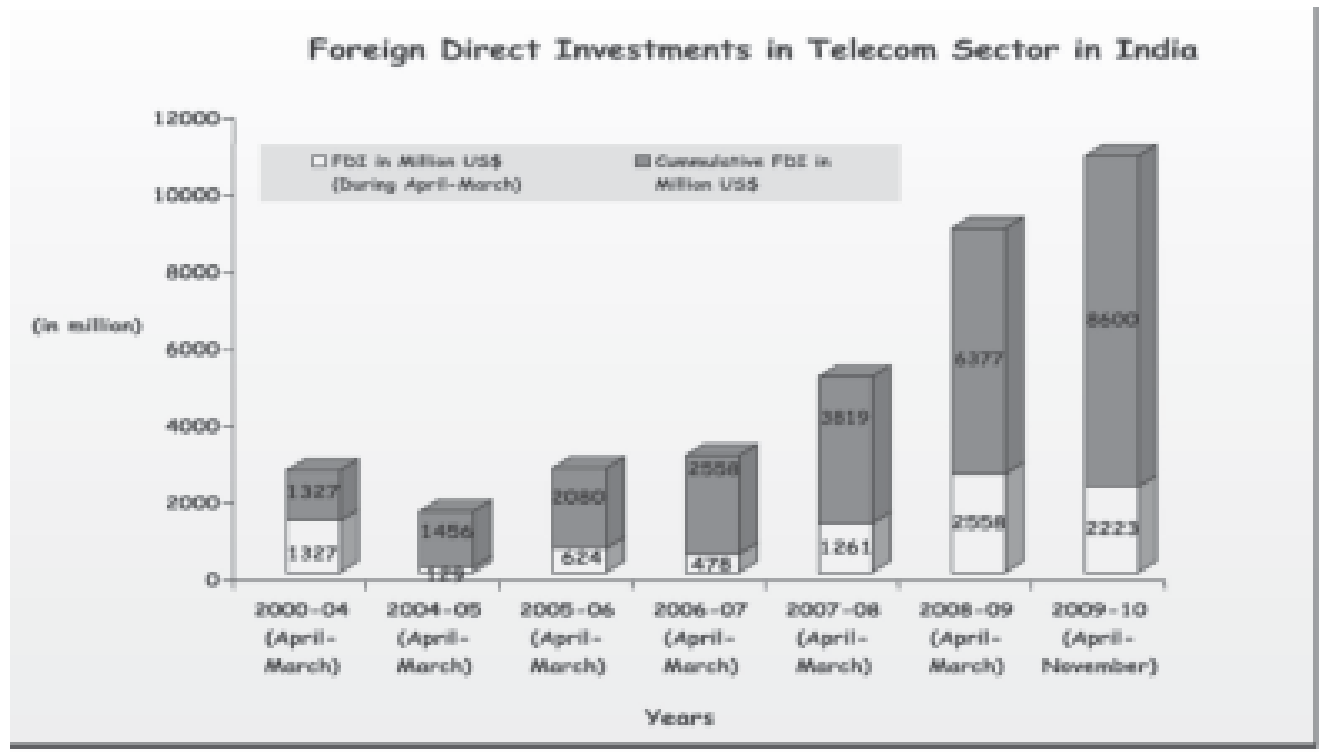

Source : TRAI

\section{G SERVICES \& INDIAN MARKET}

In a market were there is little to differentiate one service provider from another and where new offers are replicated quickly, the introduction of $3 G$ could give some operators the competitive advantage they seek. There are many new developments in the telecom sector, including the ingress of $3 G$ technology that the Indian market is witnessing. With the 3G Auctions complete and licenses granted Over 650 million strong mobile connected population is waiting for the widespread commercial launch of $3 G$ services which currently is being provided in a limited way by only Public Operators. Mobile subscribers will experience a revolutionary change in the way telecom services will be available to them. It represents a paradigm shift from voice-centric world of the previous generations of wireless networks to the multimedia-centric world of 3G.Simply put it will shift the focus from the ears to the eyes. The $3 G$ platform will allow operators to offer bandwidthintensive applications such as Video conferencing, T.V \& Video on demand, Social networking and Location Based Services (LBS). Some of the factors that could possibly trigger spread of $3 \mathrm{G}$ among Indian subscribers include:
- $700+$ million mobile subscribers, all potential $3 \mathrm{G}$ converts

- Availability of low cost handsets

- Lack of availability of broadband services

- $3 G$ enabled handsets already in market

- Young demographic profile of users

- Enterprises

- High use of VAS by other sectors

A study commissioned by international industry group GSM Association and conducted by consultancy PricewaterhouseCooper (PWC) is instructive. The study projects the number of $3 \mathrm{G}$ customers in India at 107 million by 2015. Initially the rollout is expected to be more focused in urban areas. There in no doubt that $3 G$ represents the next big thing in mobility. 


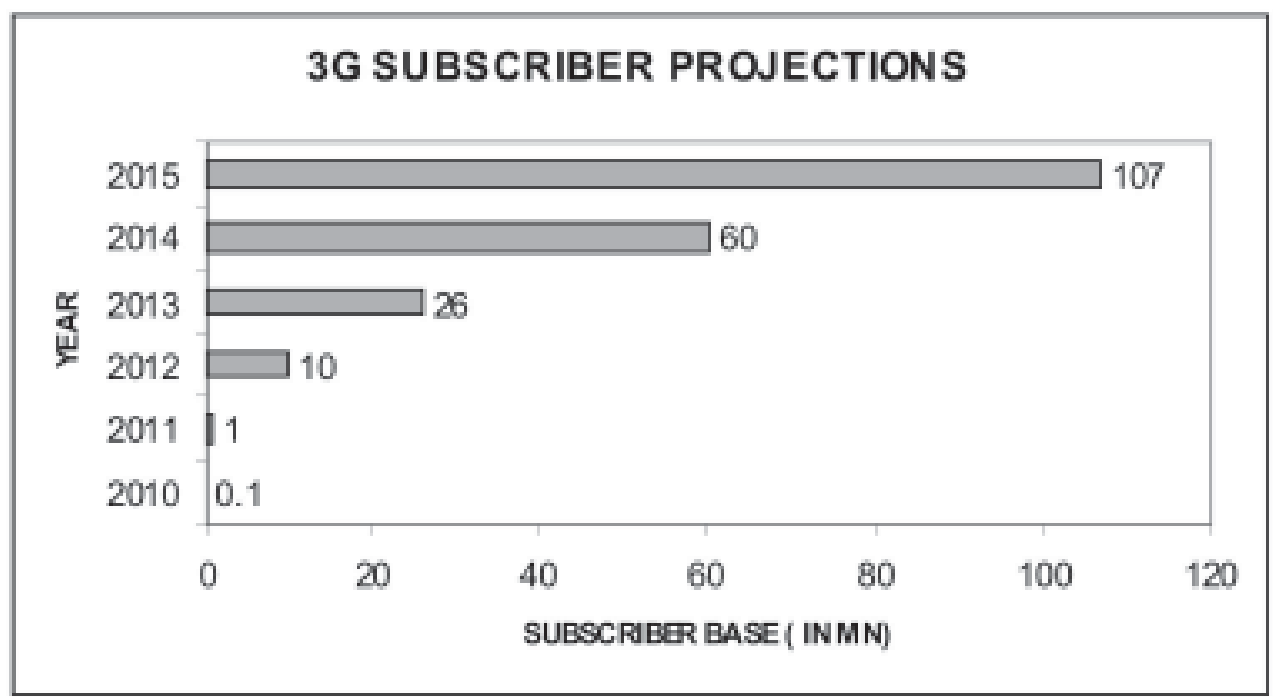

Source : PWC Analysis

The introduction of $3 G$ will thus, not only provide operators with an opportunity to enhance their service offerings and expand service to rural areas, but in the process, also generate new revenue streams for the operators, which is much required in a scenario of rock bottom tariffs and ever falling ARPUs

\section{INDIA AS AN EMERGING VALUE-ADDED SERVICES MARKET}

Indian Communication Industry has a flourishing future in its value-added services market. Telecom operators are looking at MVAS as the next wave for growth and a large chunk of revenue is expected to flow in from VAS in the near future.

Mobile value-added services (M-VAS) is the ability for cellular operators and service providers to charge a premium price for the services (beyond voice conversation) they offer to their subscribers (mobile users). Some of the services include: SMS (text messages), MMS (multimedia messages), USSD (interactive menu based services), CRBT (caller ring back tone), video streaming, mobile advertisements, participation in polls and contests, location based services, mCommerce (financial transactions), Instant messaging, Infotainment services (news, weather reports, songs, recipes ), content downloads (wallpapers, screen savers, games, ring tones), down loadable mobile applications.

The Indian value added services (VAS) segment is expected to log in a turnover of over Rs 200 billion by the year 2015. The expansion of mobile subscribers' base in rural areas presents a great opportunity to the mobile value added services industry to grow. This growth in VAS market is propelled by:

- The booming Indian economy

- Increasing user comfort with basic mobility services

- Personalization of content and devices

- $\quad$ Market Size

- Introduction of 3G 


\section{Mobile VAS Revenues in India (Rs Crores)}

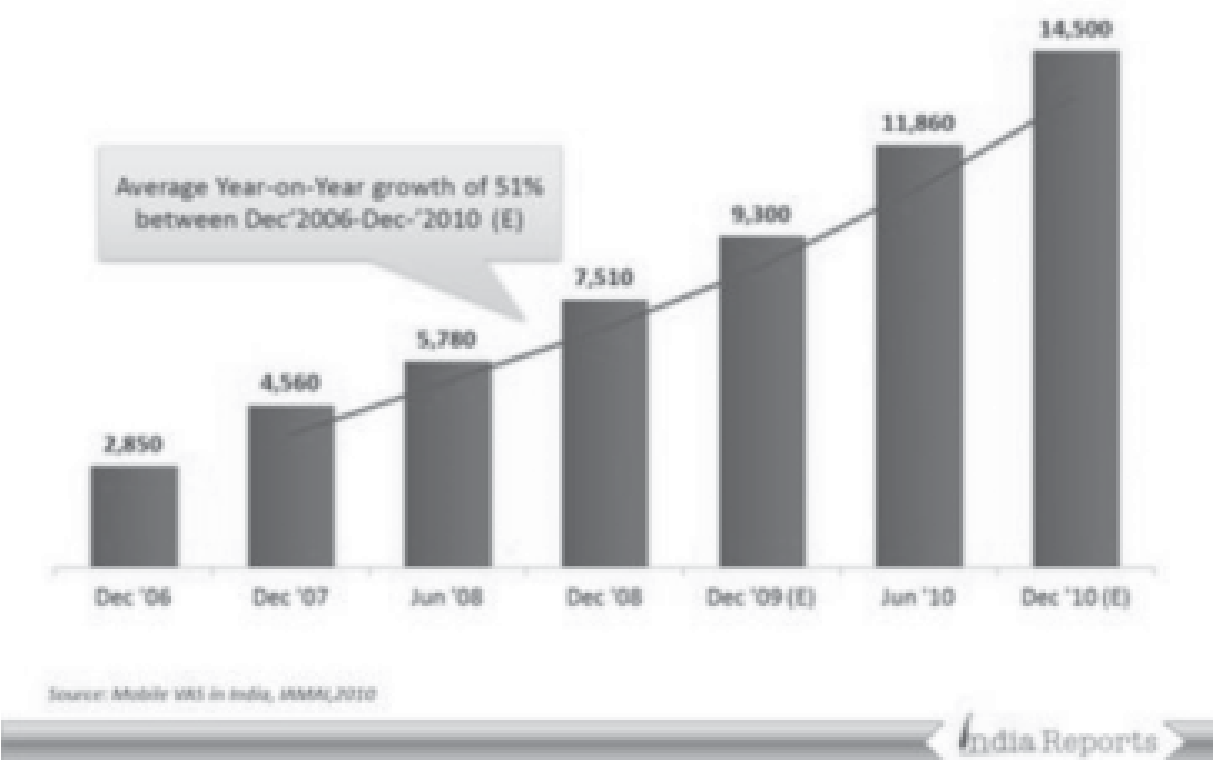

Source : IAMAI

According to an IAMAI (Internet \& Mobile Association of India) report, the mobile value add services industry is expected to touch Rs 14,500 crores by Dec 2010. The industry has grown from INR 2850 crores (in 2006) to INR 9,300 crores (in 2009). As of now, network operators have reported low MVAS revnues (10-14\%). Industry watchers believe there are new opportunities for expansion.

As the Indian mobile communication industry faces aggressive competition with numerous players in the market, services providers have lower profit margins due to lower ARPU's (Average Revenue Per User ). Given the challenges posed by the Indian mobile telephony market, MVAS is likely to become a tool for additional revenue, service differentiation, and customer retention.

\section{MOBILE NUMBER PORTABILITY (MNP) IS A REALITY}

The introduction of Mobile Number Portability is considered good news for consumers. The technology will allow subscribers to retain their old mobile number even after they decide to change their service provider. Telecom Regulatory Authority of India
(TRAl) has issued an official notification for the implementation of the Mobile Number Portability (MNP) across India from January 20 th 2011.

The initial churn reports with respect to subscribers willing to avail of MNP to switch operators are fast emerging on the horizon. Though, most of such reports are limited to the Haryana circle where MNP was implemented way back in November 2010; analysts are of the opinion that the trend could be more or less similar across the country. While the initial estimates suggest that hardly 140,000 subscribers, or $0.75 \%$, opted for MNP to ditch their current mobile operators; a Swayam-numvar survey indicates that $58 \%$ of the subscribers are more than willing to log on to telecoms that provide better services.

This IBN survey finding provides that Airtel was the most preferred operator with $26 \%$ respondents voting in its favor, followed closely by Vodafone (21\%) and Idea (13\%). Idea came at a distant $3^{\text {rd }}$ position despite having launched a big advertising campaign - "No Idea? Get Idea" 


\section{Which operator will you switch to?}

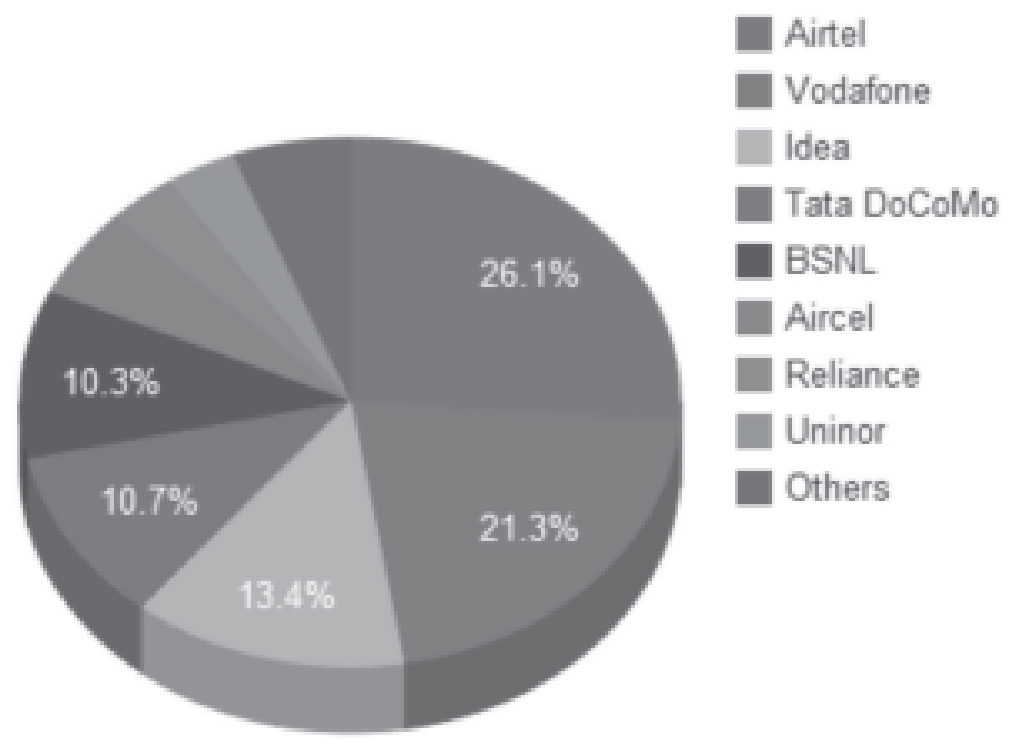

Network coverage (34\%) and tariff rates (30\%) emerged as the top two reasons as to why respondents want to avail of MNP while retaining their number.

\section{Why do you want to switch operators?}

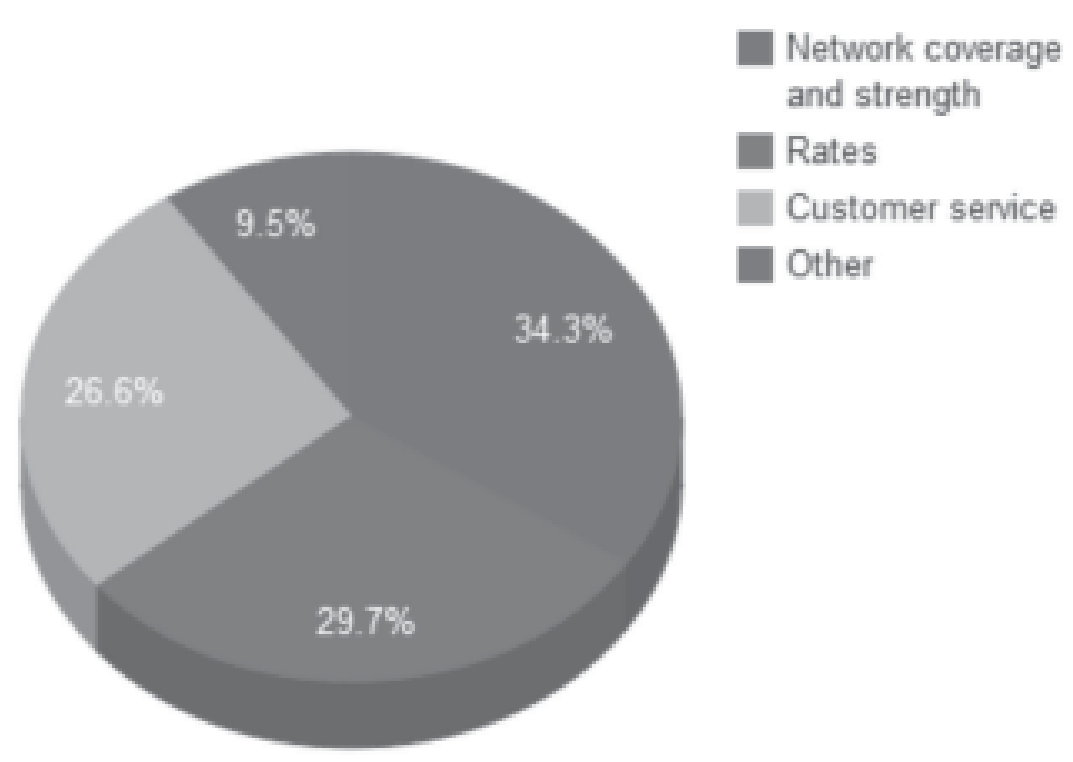

Network Coverage was considered to be the major reason why users wanted to shift from their existing service provider. 
The early set of numbers from Haryana provides that BSNL and Reliance Communications have emerged as biggest losers in the race of poaching subscribers led by MNP.

\begin{tabular}{|l|c|c|c|}
\hline \multicolumn{4}{|c|}{ MOBILE NUMBER PORTABILITY CHURN } \\
\hline Operator & No. of users joined & Exited & Net Gain / less \\
\hline BSNL (GSM) & 5,302 & 25,805 & $-20,503$ \\
\hline Reliance Com (GSM) & 988 & 8,888 & $-7,900$ \\
\hline Reliance Com (CDMA) & 192 & 6,003 & $-5,811$ \\
\hline Tata Tele (CDMA) & 725 & 7,915 & $-7,190$ \\
\hline Tata Tele (GSM) & 16,107 & 6,811 & $+9,296$ \\
\hline Vodafone (GSM) & 30,015 & 9,297 & $+20,748$ \\
\hline Airtel (GSM) & 18,271 & 10,837 & $+7,434$ \\
\hline Idea Cellular & 13,741 & 15,604 & $-1,863$ \\
\hline Aircel & 10,608 & 1,279 & $+9,329$ \\
\hline
\end{tabular}

Source: The Hindu

While the state-owned operator has net lost 20,503 subscribers, the Anil Ambani-led Reliance group finds itself short of a net 13711 subscribers (GSM+CDMA). In MNP, one's loss is other's gain! The subscriber loss recorded by BSNL, Reliance and Idea has proved to be a welcome business_opportunity for Vodafone $(20,748)$,Airtel $(7,434)$ and even the late entrant Aircel which net gained by 9,329 subscribers.For Tatas, the CDMA business has been a net loser. However, its GSM business- Tata Docomo which has pioneered innovative marketing strategy in Indian telecom market has been a great leveler for the group under its competitive DoCoMo brand.

As the craze for poaching customers sizzle-up, telcos have also started to waive-off MNP port-in charges of Rs.19 as an extra incentive to the new customers. Players like Vodafone Essar,Loop Mobile and MTS have launched attractive consumer offering to hedge against the exodus. Bharti Airtel, has sent out text messages to select subscribers saying they will get a $10 \%$ discount on their bill for the next two months. All service providers are gearing up for the change and possible future switch over of users to competitors

Vol 4 Issue 2 September 2011

\section{CONCLUSION}

Mobile Communication Industry is one of the fastest growing industries in India. With more demand the growth prospects will also be very high in this industry with good packages since the companies are going to make a lot of profits in this emerging segment. With the introduction of $3 G$ a new era awaits the Indian mobile service users. With a faster and more robust Internet, better access to data services including e-commerce, social networking and telemedicine. Also ready are mobile device manufacturers with a slew of $3 G$ handsets; providers of hosting, billing and network management services with expanded offerings; and content providers selling cell phone ring tones, wallpapers and graphics. Amid that euphoria, industry observers worry about the "winner's curse" of successful bidders paying too much for the licenses, which ultimately could decrease margins and dampen future investment enthusiasm. Intense price competition is steadily eating into mobile operators' earnings, and that could force marginal players in the $3 \mathrm{G}$ market to eventually succumb to a wave of consolidation. To recover their investments, the $3 G$ spectrum winners will have to focus on customers with high ARPUs, or the top 100 million subscribers who want more data services. 
To add value and to reduce the effect of falling ARPUs and stiff competition, VAS will be taken to a new level and will keep on progressing with newer applications and apps stores, and with the coming in of $3 G$, especially. The launch of MNP and $3 G$ has resulted as a good move for the Indian service users. It puts the service providers on their toes and will make them focus on delivering value to the consumers, giving the common man the power to choose.

Considering the demographic profile, disposable incomes and presence of high-end customers, analysts believe over the next three years the quality of service and customer experience will play an important role in a customer's choice for an operator rather than pricing. Telecom in India is witnessing drastic changes and tremendous growth on all fronts in the last decade, and continues to grapple with more just around the corner.

\section{REFERENCES}

1. $3 G, M N P$ to define 2011 telecom story, Times of India ,Dec 23, 2010

2. Hello Tommorrow -Kushan Mitra,Manu Kaushik Business Today, September 5, 2010
3. $58 \mathrm{pc}$ want to switch mobile operators. The rest? , ibnlive.com, Jan 21, 2011

4. MNP Churn Numbers: Vodafone gains \& BSNL falters!, Viral Dholakia, ibnlive.com, Jan 21 , 2011

5. Change is the Path to Development - Erwann Thomason, Voice \& Data, February 10, 2011

6. A Study of the Mobile Value Added Services (MVAS) Market in India, Boston Analytics, October 2007

7. MVAS to touch Rs. 48,000 crore by 2015 , cited Industry experts, February 5,2011 , http:// mobigyaan.com

8. Telecom Networking and Communications Today, December 19,2010

9. MVAS critical for inclusive growth www.mymobile.co.in, January 18, 2011

10.Mobile number portability: 80,000 opt for new perator in Haryana

11. Exchange4media, News Service, January 20, 2011 